\author{
Nataliia Orlova, \\ PhD (Candidate of Pedagogical Sciences), associate professor, \\ Department of Foreign Languages, \\ Bohdan Khmelnytsky National University of Cherkasy, \\ 81, Shevchenko Boulevard, Cherkasy, Ukraine
}

\title{
EFFICIENCY OF MIND MAPPING FOR THE DEVELOPMENT OF SPEAKING SKILLS IN STUDENTS OF NON-LINGUISTIC STUDY FIELDS
}

Teaching the art of profession-related communication to students of non-linguistic study fields allows instructors to explain their students how to keep up the conversation using facts, data, concepts etc. specific to the area of their future profession. It activates the acquisition processes as well as increases students' motivation to study. The formation of oral monologue speaking skills in students of non-linguistic study fields is one of the tasks within the course of Foreign (English) Language for Specific Purposes. This process is associated with certain difficulties, which can inhibit learning and demotivate students to study. Among strategies and techniques aiding learning that can be used to improve performance and study outcomes during the course and can be implemented for the enhancement of speaking on occupation-related topics, the mind mapping technique is of specific relevance. It can serve as an interesting and useful tool serving to enhance quality of oral speaking skills in the students majoring in Psychology as the representatives of non-linguistic study fields. The article analyses the carried out research concerning the facilitating impact of mind mapping on the oral speech performance of Psychology students. The study hypothesis implies that the use of the mind-mapping technique in the process of preparing for and presenting the talk in the study sessions enhances students' oral monologue speech performance. In order to check the hypothesis, we have conducted the experiment in Bohdan Khmelnytsky National University of Cherkasy at the Department of Psychology. The study involved 46 first-year students, including 34 female and 12 male participants. The respondents were randomly assigned to the experimental mind-mapping group of 23 students (including 6 males) and the control group of 23 students (including 6 males as well). The students in the experimental group were involved into the experiment using the mind-mapping technique during their study, and the students in the control group continued their studying in the usual way. The hypothesis was confirmed. The mind map use stimulates activity of both brain hemispheres, thus making it easier for students to memorise thematic vocabulary, follow the logical sequence of the talk when speaking. The research findings have shown the effectiveness of implementing the mind-mapping technique into the university course of teaching English for Specific Purposes to develop, advance and master students' professional communicative competence. Consistent use of mind maps will also promote the educational process efficiency and have positive effects on the general formation of competitive skilled specialists.

Keywords: mind maps, mind-mapping technique, English for Specific Purposes, oral monologue speech, nonlinguistic study fields.

\section{Introduction}

The process of learning a foreign language by students of non-linguistic study fields has been considered to be relevant during the recent decades. Present-day professional requirements to prospective specialists include the high level of profession-related knowledge and skills as well as combination of willingness and ability to master the professional proficiency, to be a competitive and mobile expert in our integrated world. Thus, these demands involve fairly good command of a foreign language both for specific and general purposes. Consequently, the final goal of higher education is to train qualified and competitive specialists capable of meeting the employers' requirements built upon certain competences of specific character with the profound knowledge of a foreign language for professional purposes.

Today, teaching students to use the language on a daily basis as well as to know how to apply it in occupation-related situations is considered to be one of the fundamental tasks of the ESP courses. It is a common knowledge that the low level of Ukrainian graduates' and postgraduates' mobility in the domestic and international job markets results from their poor foreign languages communication skills. Besides, it is difficult to overestimate the role of ESP at the stage of active studying before graduating. Here we can speak about not only increasing levels of ESP knowledge but also about providing the students with its practical aspects. To ensure this, it is necessary to form and develop students' skills of seeking ways and means of solving cognitive and vocational tasks using ESP. They will learn how to keep their occupationrelated conversation with facts in their future work area, how to deepen their knowledge using the recent research data and findings available in international journals primarily in English. Moreover, students will be able to enlarge their worldviews and improve their professional culture after having familiarised themselves with traditions and norms of the current world practice linked directly to their future work field. 
The peculiarity of teaching ESP to the students majoring in Psychology involves acquiring certain skills related to the future occupation and their further use for self-development and self-improvement. The practical goal is ESP acquisition as the means of conversation within the sphere of students' profession. The general educational aim includes expanding knowledge of the peculiarities of the lexical and terminological structure of ESP. An educative target presupposes the formation of oral monologue speaking skills [1, p. 88]. Fostering students' professional speaking skills involves demonstrating the learners they ways to keep the conversation with facts associated with their future work area, stimulates acquisition processes and motivation to studying. Engaging Psychology students into independent investigations and analysis of recent information concerning their future occupation promotes their motivation to get sufficient knowledge of ESP because the international sources both printed editions and internet resources are published in English. Just in order to work with the mentioned sources, to participate in discussions or to hold a conversation about definite aspects, nuances, concepts of psychological issues, students should possess the key terminology basis, grammar, and monologue speaking skills concerning occupation-related topics. Besides, transferring the acquired knowledge into new theoretical and cognitive as well as practical situations activating the mental processes of analysis and synthesis, comparison and classification, which are important for learning and self-perfection, will promote further consolidation of students' knowledge and achievements. The formation of oral monologue culture in students of non-linguistic fields of study as a task within the course in ESP is associated with some difficulties, which can inhibit the learning process and demotivate students taking the course. Oral monologue speech is complicated both in content aspect because students are required to know thematic information, advanced terminology at the appropriate level; and personal one as it is related to psychological issues of such kinds of verbal activity. Contextual features of oral monologue speech include informative richness, an accurate framework of organisation, a logical sequence and an ability to stick to the topic consistently. Thus, an oral message must meet the principles of coherence and cohesion. Contextual aspects also depend on students' proper choice and use of the words to express their thoughts, as well as occupationrelated, scientific and terminological vocabulary. Consequently, contextual difficulties the students may face when speaking can be divided into linguistic, related to certain characteristics of lexical elements and grammatical, concerning lack of confidence in grammatical correctness of a message. In this context, it is necessary to draw students' attention to the advantages of oral speech despite all possible mistakes as they are viewed as indicators of the stages of ESP acquisition, and are not perceived as students' failure to learn study material properly. A great number of mistakes are typical of initial stages of learning a language, and they gradually decrease as the students move up the stages. Certain aspects are associated with personal psychological difficulties that cover peculiar characteristics of individual verbal activity, attention of other people drawn to the speaker, anxiety during public performances because of previous negative experience, potentially negative expectations of combining oral speech and nervous tension of formal study environment. Whatever the nature of difficulties is, they result in low marks and achievements, reduction of interest in the subject, absence of motivation to improve the level of knowledge, etc.

Among tools and techniques used for the enhancement of academic performance in general and monologue occupation-related speech in particular, we distinguish drafting a speech plan outlining the main context, drawing supporting schemas, such as cluster maps, mind maps, concept maps, thinking maps, including flow maps, multiflow maps, etc. Mind maps as an interesting and useful tool used for the development and improvement of speaking skills in Psychology students as representatives of non-linguistic study fields occupy a special place in this list. The relevance of practical application of mind maps lies in the concept developed by Tony Buzan in 1960s [3]. It serves as a powerful graphic technique, which is a universal key to "unlock" brain potential. Unlike other kinds of supporting and cluster schemes that are given to students in a completed form, mind maps are meant to be designed and drawn by students themselves. It results in better knowledge of key concepts and memorising thematic lexical material. The importance of mind maps implementation when teaching oral monologue speech on occupation-related topics to students is caused by the following factors. Firstly, this technique promotes organising the content of the topic studied, and it is up to the students to compose and structure it for the further development and study. Secondly, it is very helpful for effective learning, improvement of the ways of memorising information. This technique increases students' productivity and achievements. Thirdly, it assists in defining and understanding the structure of the topic being studied. It also helps making easy associations, generating new ideas and their effective implementation into a mind map. A properly made mind map demonstrates understanding of a topic as a whole, taking into account all relations between its structural elements. It is known as a significant feature of mind maps, because it means that students require less time for material review as they can refresh their knowledge just by taking a glance at their completed mind maps. The mind mapping technique is an effective mnemonic device. By remembering the shape and structure of the map, students also memorise the pieces of information within those structures. In addition, mind maps are especially useful for summarising and consolidating information obtained from different researches or other sources, presenting information in a format that shows the overall structure of the theme. The free use of colours, images, pictures, and key words help make learning more interesting and make the students more motivat- 
ed to remember important facts, details, etc. Another exceptional feature of mind maps is that they cannot be correct or incorrect because they are just a type of brainstorming. Mind maps can be either useful or useless. They cannot be assessed or judged because their purpose is to reveal the general picture of a topic for enhanced learning outcomes.

World scientists and educators have been studying mind maps and their peculiar features very vigorously. A. Buran and A. Filyukov (2015) studied the mindmapping technique in language learning by technical students [2]. R. Hanewald (2012) pointed out the openended nature of mind maps that provided students with greater control over their training [4]. Daniel Long and Dr. David Carson (2011) investigated how thinking maps could be used by students to achieve greater understanding in comparison to the students using traditional notetaking strategies [7]. Cathy-Ann Radix and Azim Abdool (2013) examined how mind maps can be used for the assessment and improvement of learning quality in higher education within the constructivist learning practices [9]. Sherri Melrose (2013) also studied usage of mind maps within the constructivist learning environment [8]. Mithra Zahedi and Lorna Heaton (2016) discussed the use of mind maps by interdisciplinary teams of students during a collaborative design activity [11]. Joeran Reel and Stefan Langer (2011) studied mind maps created with assistance of mind-mapping applications such as Docear and MindMeister. They analysed the mind maps structure and the information they covered [10]. Recently, the TonyBuzanLtd company issued a special edition of research reports devoted to the mind-mapping technique. Among those studies, we believe that two works are worth noting. Genevieve Zipp and Catherine Maher (2013) attempted to determine the prevalence of mind-mapping technique in a health science professional curriculum "Physical Therapy" and to clarify the existence of the relationship between mind maps and the use of this technique in studying [12]. In their work, Brett D. Jones, Chloe Ruff et al. examined how students' motivation differed depending on types of mind-mapping activities they had been engaged [6].

However, despite the existence of numerous studies concerning the use of mind maps in education in general, there are no studies describing their role in teaching oral monologue speech to Psychology students. Thus, certain aspects depicting the impact of mind maps on the enhancement of study outcomes of teaching ESP to Psychology students, the use of mind mapping in designing and drafting as well as presenting oral topics are still unexplored.

The paper aims to study and describe the ways the mind mapping technique influences the process of the development of oral monologue speaking skills, and to clarify whether it has positive effect on students' performance enhancement. In order to achieve the objective, the following tasks have been defined:

1) to identify the role and place of mind maps in teaching oral monologue speech;

2) to determine facilitating factors of the mindmapping technique use by students of Psychology in the process of preparing for oral speech on a certain topic;

3 ) to set and verify peculiar features of using mind maps.

\section{Research methods}

To achieve the objective set, we applied the following methods: 1) theoretical methods of analysing scientific and methodological literature on the topic under research; modelling and development of the methodological system and its educational and methodological implementation; 2) empirical methods of pedagogical experiment to test the efficiency of the methodical system of using mind maps in the educational process.

The research hypothesis implies that the mindmapping technique is efficient in developing oral monologue speaking skills in students majoring in Psychology. The key assumption is that work on drawing mind maps using thematic lexical material and considering grammar relations, with the further implementation of individually created mind maps as the supporting schemes can decrease the difficulty level, increase the quality of the material acquisition, and thus, improve students' academic performance and psychological atmosphere in the classroom. To support our assumption, we assigned groups for conducting an experiment involving the technique of mind mapping. The experiment involved 46 first-year students of Psychology department of the Bohdan Khmelnytsky National University of Cherkasy (34 female and 12 male students aged 17-18 years). The participants were randomly divided into two groups: the control group of 23 students, including 6 male students, and the experimental mind-mapping group of 23 students with 6 males in it. Both groups were working on the topic "Psychology as a Science: Major Schools of Thought in Psychology", at the end of which they had to perform an oral talk. According to the experiment conditions, the control group used standard linear texts, whereas the members of the experimental group designed and drew individual mind maps.

Prior to the beginning of the experiment, students were explained the basic concepts and principles of mind mapping. They were told that the mind map is a kind of a scheme or a diagram used to represent or outline the required information visually (Fig. 1). Mind maps allow the students' brains to organise and understand information faster and better [3, p. 4]. 


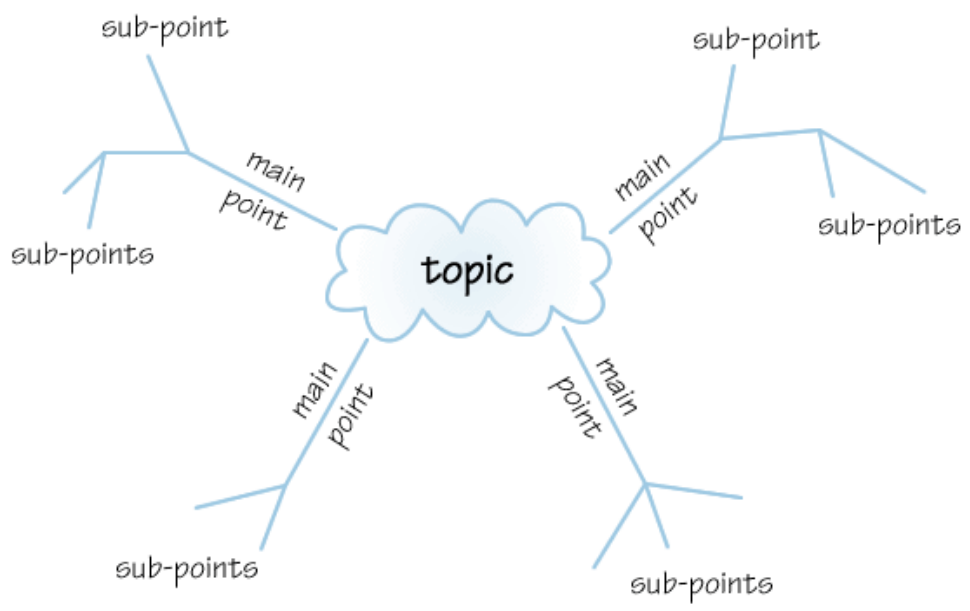

Figure 1.

Students were shown essential characteristics of mind mapping with the necessity to identify and place the central topic at the centre of a mind map, as it will serve the focal point of the map. Then, the main topics are lo- cated radiating from the central image, and after that, the second level will form as the branches of the main topics. So, they will form a connected nodal structure (Fig. 2).

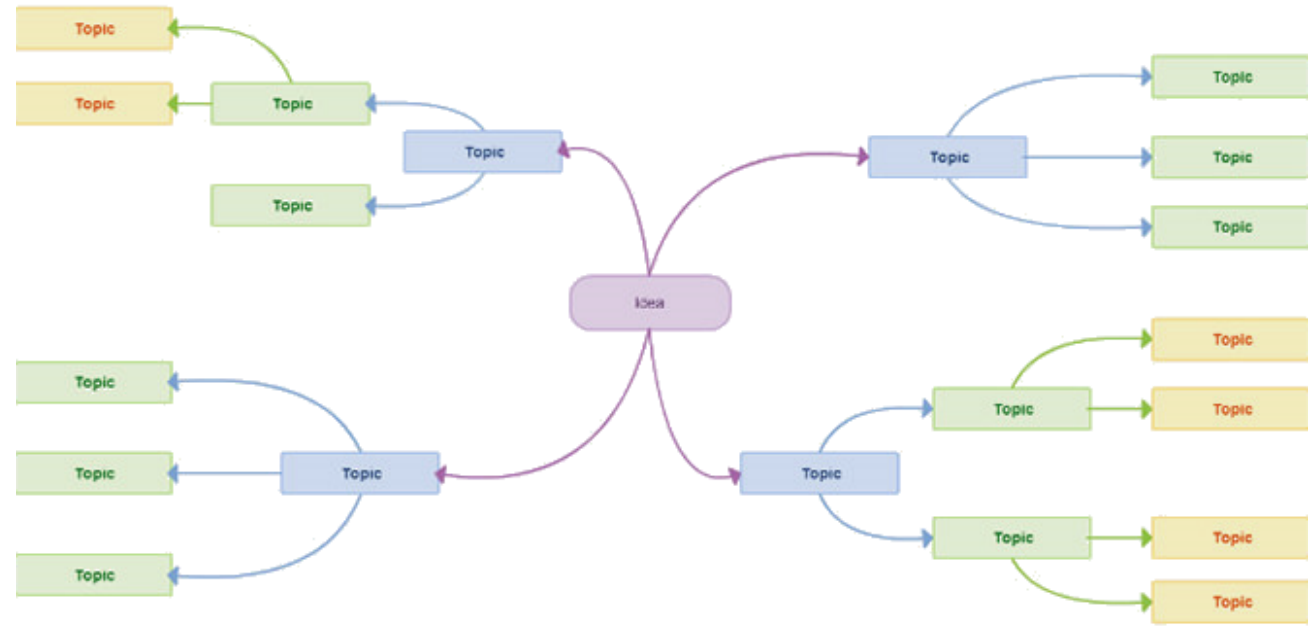

Figure 2.

These principles were applied by the experimental group participants while making their own mind maps on the topic for the further use of them when working on their oral talks.

\section{Research results}

The mind maps were built considering necessary structural elements and principles. The final stage of drafting and presenting mind maps was preceded by a complete cycle of thematic practical lessons, which included several phases. They involved introduction of lexical elements, reading and analysing a key thematic text, doing exercises to form the skills of active use of lexical and terminological elements, mastering activity of an oral speech presenting using current thematic vocabulary. The participants of the experimental group were using the mind mapping technique through all those stages. At the last lesson, students were given an opportunity to apply their mind maps when speaking on the topic (Fig. $3)$. 


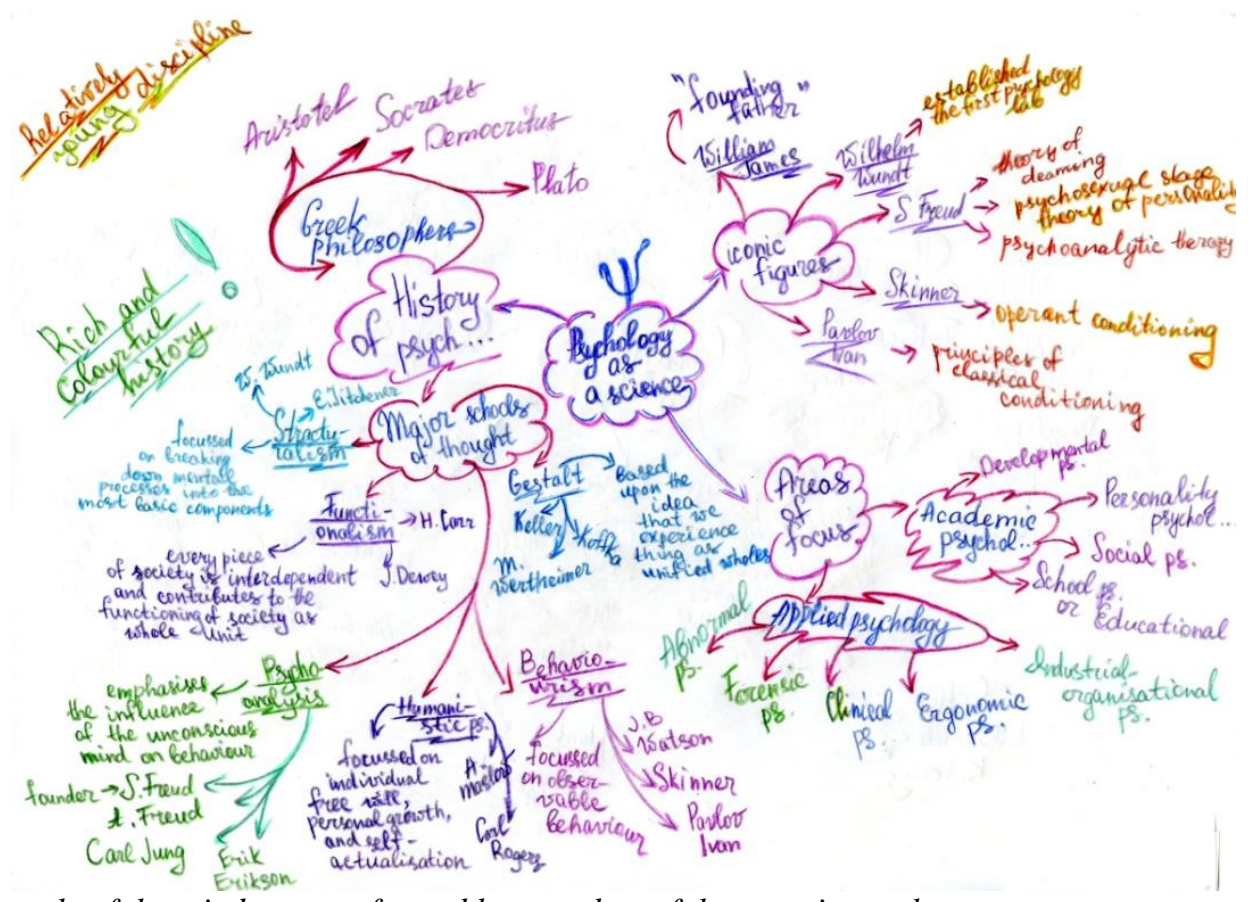

Figure 3. Example of the mind map performed by a student of the experimental group

The mind map on the topic and the talk should involve the following terms, terminological phrases, key words and word-combinations: schools of thought, historical approaches, current perspectives, psychological thinkers, areas of focus, key assumption, evolve out, human mind and behaviour, iconic figures, view people's thought, thinking processes, structuralism, functionalism,
Gestalt psychology, psychodynamic approach, behaviourism, humanistic psychology, cognitive psychology, social perspective, developmental psychology, comparative psychology, biopsychology, personality psychology, abnormal psychology, positive approach, origin, drawbacks, benefits, etc. (Fig. 4, 5).

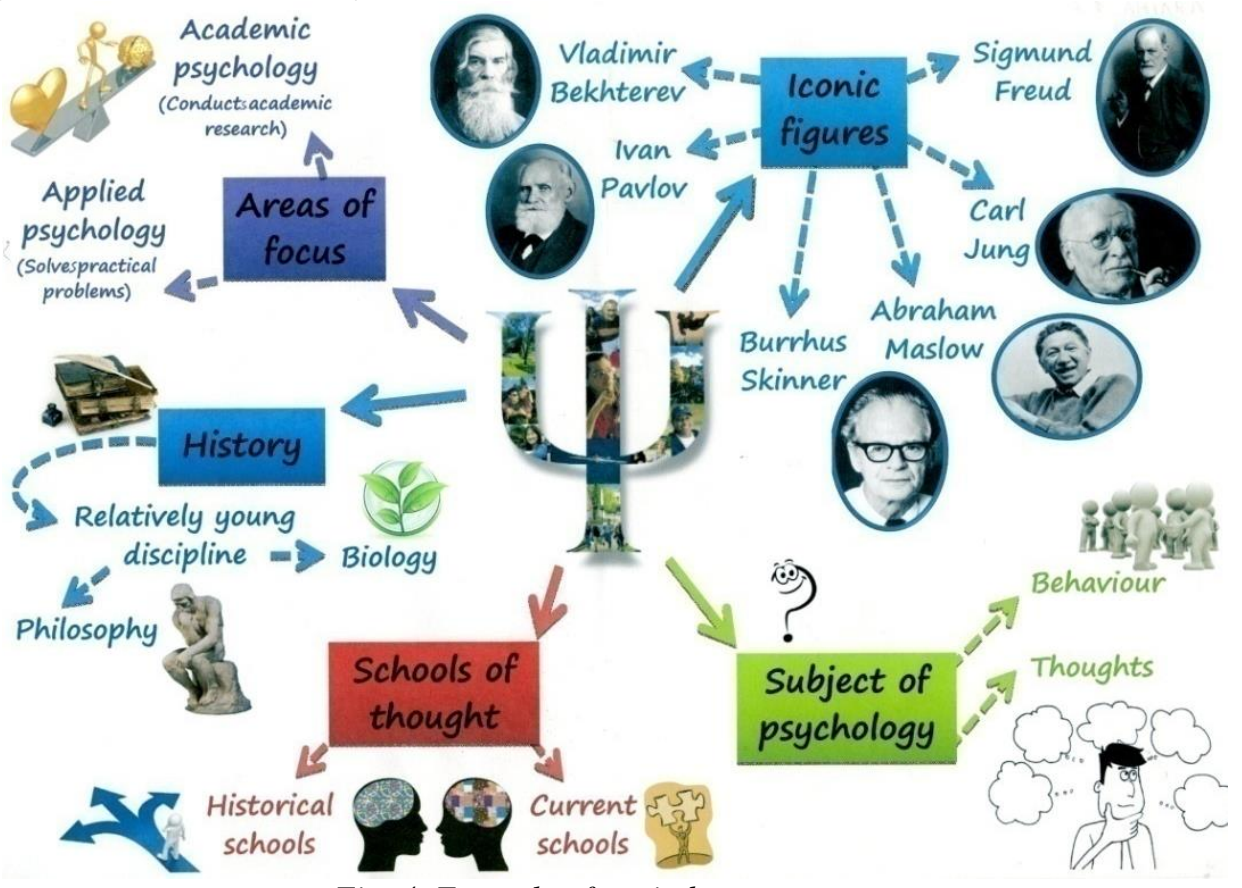

Fig. 4. Example of a mind map structure 


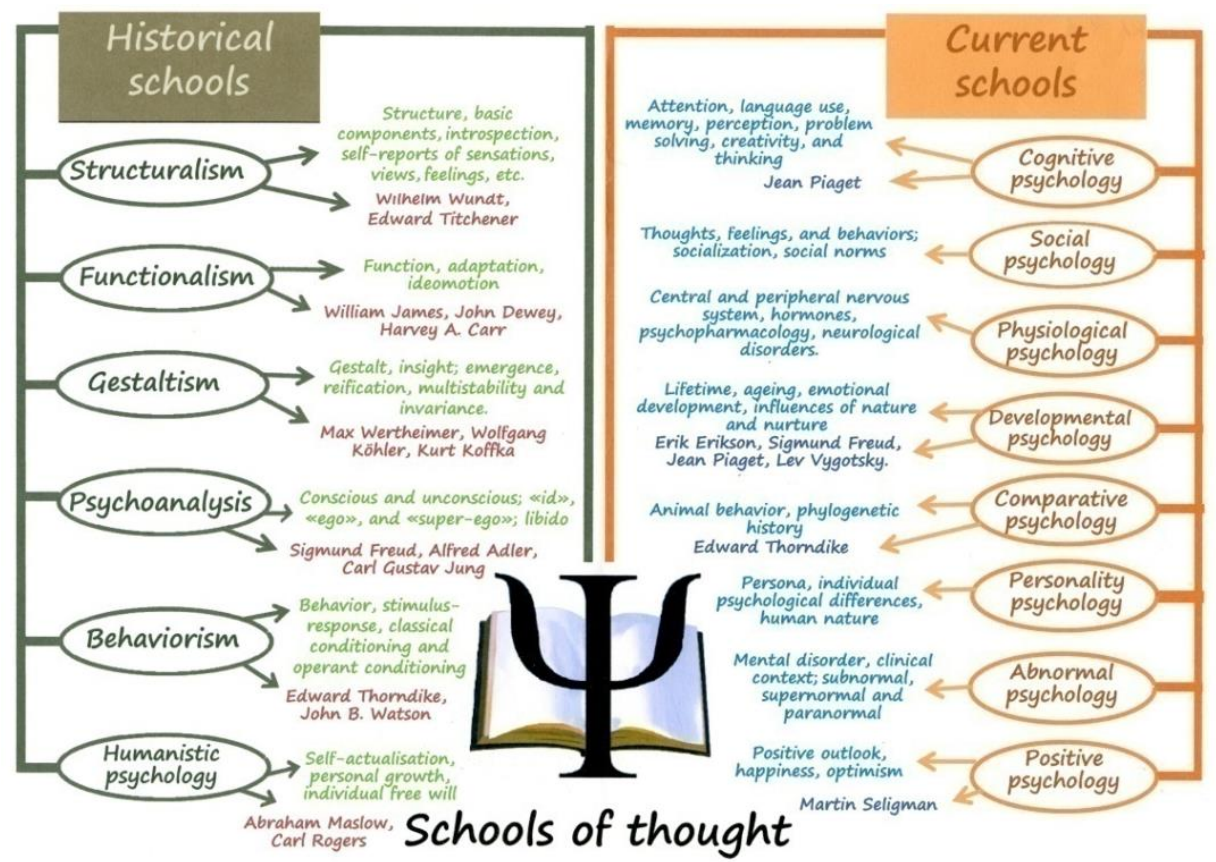

Fig. 5. Example of a mind map structure

Such aspects as knowledge and understanding of lexical elements, following the logical sequence of speech, fluency, overall thematic awareness, which includes the ability to navigate the topic quickly and make changes in presentation were assessed.

After the final examination, we have obtained the following results. The students of the experimental group have demonstrated better outcomes in the knowledge and understanding of thematic vocabulary: 9 students have shown excellent performance, 10 students have got good marks, just 4 participants have got "satisfactory" results. There were no students who failed the task (Table 1).

\begin{tabular}{l|c|c}
\multicolumn{2}{c}{$\begin{array}{c}\text { Experimental group: knowledge and understanding of thematic lexic } \\
\text { Marks }\end{array}$} & $\begin{array}{c}\text { Number of stu- } \\
\text { dents }\end{array}$ \\
\hline Excellent & 9 & $39.13 \%$ \\
\hline Good & 10 & $43.48 \%$ \\
\hline Satisfactory & 4 & $17.39 \%$ \\
\hline Unsatisfactory & 0 & -
\end{tabular}

The students in the control group have shown the following results: 2 participants have had excellent marks, 9 students have got good marks, 8 people have demon-

Table 1.

strated satisfactory performance and 4 participants have failed the task (Table 2).

\section{Control group: knowledge and understanding of thematic lexical elements}

\begin{tabular}{l|c|c}
\multicolumn{1}{c|}{ Marks } & $\begin{array}{c}\text { Number of stu- } \\
\text { dents }\end{array}$ & Percentage \\
\hline Excellent & 2 & $8.698 \%$ \\
\hline Good & 9 & $39.13 \%$ \\
\hline Satisfactory & 8 & $34.782 \%$ \\
\hline Unsatisfactory & 4 & $17.39 \%$
\end{tabular}

Figure 1 demonstrates the ratio of knowledge and understanding of thematic lexical elements in students of the experimental and control groups. 


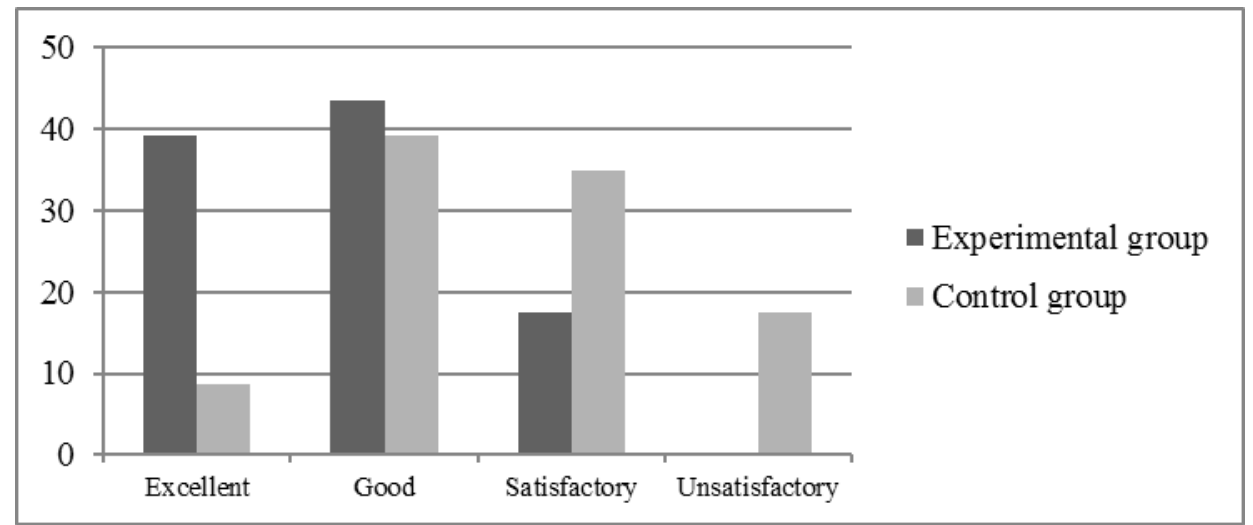

Fig. 1. Comparative ratio of the thematic vocabulary knowledge in control and experimental groups

Logical sequence and speech fluency turned out to be better in students of the experimental group. Twelve participants of the experimental group performed their talks following the contextual and logical sequence, without skipping from one thing to another and omitting some parts. Unlike them, the students of the control group mainly failed to comply with the requirements of logical sequence and speech fluency. Overall, only 18 participants showed good and satisfactory performance (Table $3,4)$.

Table 3.

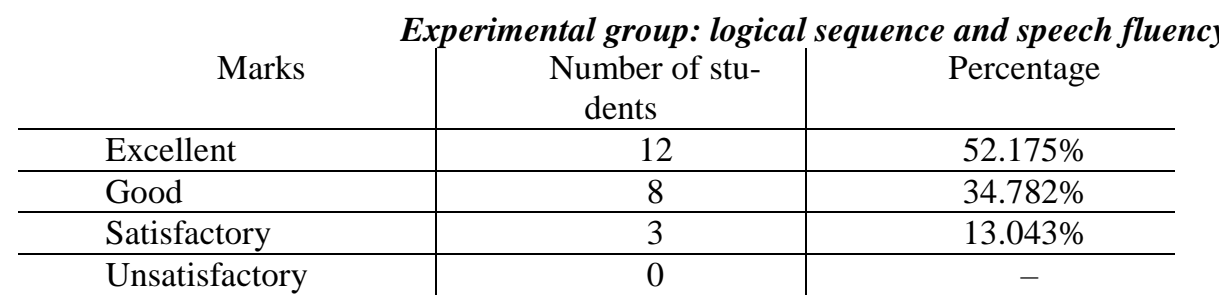

Table 4

\begin{tabular}{l|c|c}
\multicolumn{1}{c}{ Marks } & $\begin{array}{r}\text { Control group: logical sequence and speech fluency } \\
\text { Number of stu- } \\
\text { dents }\end{array}$ & $\begin{array}{c}\text { Percentage } \\
\end{array}$ \\
\hline Excellent & 0 & - \\
\hline Good & 10 & $43.48 \%$ \\
\hline Satisfactory & 8 & $34.782 \%$ \\
\hline Unsatisfactory & 5 & $21.738 \%$
\end{tabular}

Figure 2 shows the ratio of students' compliance with logical sequence and speech fluency in the experimental and control groups.

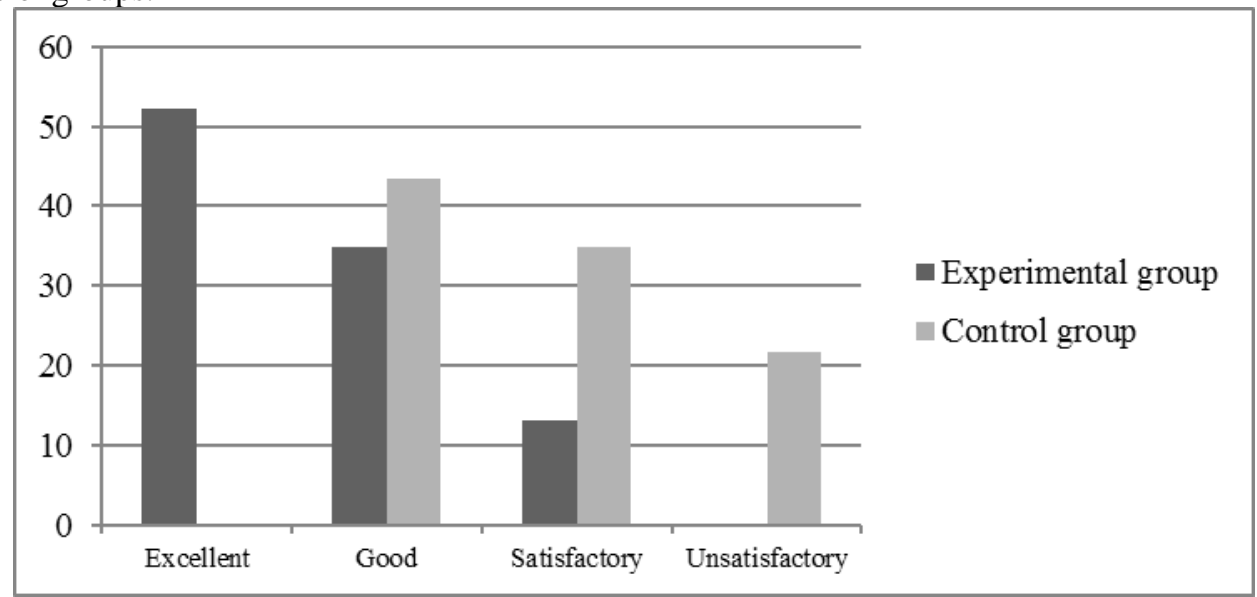

Fig. 2. Comparative ratio of experimental to control groups in logical sequence and speech fluency 
Thus, the findings have demonstrated $30.43 \%$ enhancement in knowledge and understanding of thematic vocabulary and $52.175 \%$ improvement in logical sequence and speech fluency in the experimental group in comparison to the control group.
Overall performance enhancement (based on obtained "Excellent" and "Good" marks) reached 91.304\% in the experimental group and $43.48 \%$ in the control group that was $47.824 \%$ higher than in the latter (Tables $5,6)$.

Table 5.

\begin{tabular}{l|c|c}
\multicolumn{1}{c|}{ Marks } & $\begin{array}{c}\text { Experimental group: overall performance } \\
\text { Number of stu- } \\
\text { dents }\end{array}$ & Percentage \\
\hline Excellent & 11 & $47.826 \%$ \\
\hline Good & 10 & $43.478 \%$ \\
\hline Satisfactory & 2 & $8.696 \%$ \\
\hline Unsatisfactory & 0 & -
\end{tabular}

Table 6 .

\begin{tabular}{l|c|c}
\multirow{2}{*}{ Marks } & \multicolumn{2}{c}{$\begin{array}{c}\text { Control group: overall performance } \\
\text { Number of stu- } \\
\text { dents }\end{array}$} \\
\hline Excellent & 1 & Percentage \\
\hline Good & 9 & $4.35 \%$ \\
\hline Satisfactory & 9 & $39.13 \%$ \\
\hline Unsatisfactory & 4 & $17.39 \%$
\end{tabular}

Figure 3 shows the comparative ratio of students' overall performance in the experimental and control groups.

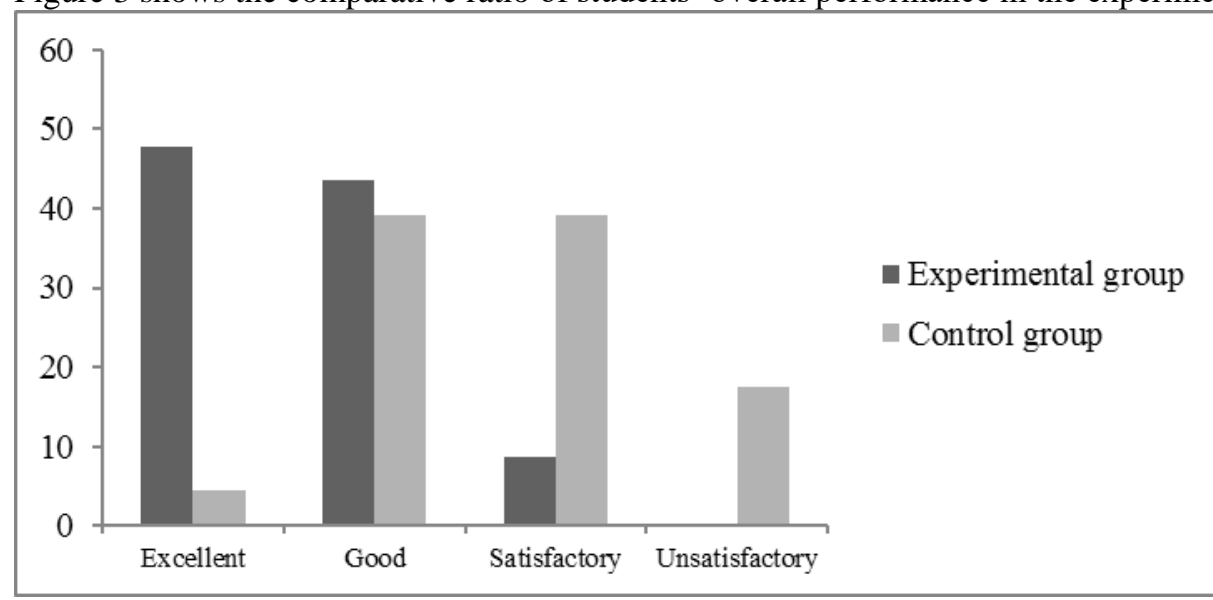

Fig. 3. Comparative ratio (\%) of experimental to control groups in overall performance

\section{Discussion}

The findings obtained have confirmed the hypothesis about facilitative impact of the mind mapping technique on learning thematic material and preparation for an oral monologue speech. Mind maps create conditions for practical application of previously acquired knowledge, and have as well motivating and thought-provoking influence on students' speaking activity, as they serve the supporting technique for the development and improvement of speaking skills. The mind-mapping technique has a facilitative effect on the activity of the cerebral cortex areas, including the executive functions of brain associated with learning and studying. As the recent studies have shown [4], the left hemisphere plays a prevailing role in verbal activity and speaking, logical, rational and analytical thinking, whereas the right hemisphere is responsible for complex stimuli processing. Consequently, the brain left hemisphere works with words, logics, numbers, sequence linearity, analysis, and lists, but the right hemisphere is linked to rhythm, imagination, awareness, day-dreaming, colours and dimensions. Most of information, subjects, and phenomena in educational environment is organised in a linear manner, which is mainly aimed at activating the left hemisphere. Here we can refer to lined paper, linear tools and strategies of taking notes, words and numbers as the main items to organise the order, clear logical arrangement of everything we do or write, classrooms and study spaces mostly organised in lines and many more. However, it is highly necessary to involve the right hemisphere responsible for multi-coloured images, pictures, creativity, intuition, synthesis [3, p. 6, 7]. This kind of integrated nature is typical of the mind-mapping 
technique with its facilitating impact on students' performance and learning outcomes enhancement. While using the mind maps, students have gained opportunities to increase abilities and skills of memorising facts, words and images, producing new ideas, analysing events and outcomes, organising and working with data, showing accurate structural characteristics of certain concepts, etc. The experiment findings are of practical value for teaching ESP. Besides the fact that our study on implementation of mind maps within the sphere of teaching ESP for Psychology students requires further long-term experimental studies, our data have confirmed practical effectiveness of mind mapping implementation that promotes enhancement of the development and perfection of students' speaking skills and also contributes to the positive changes in quality of oral monologue speech.

\section{Conclusions}

The research findings, which support the assumption of facilitating function of mind maps and their underlying explanatory illustrative mechanisms in teaching and learn-

\section{REFERENCES}

1. Orlova, N.V. (2010). Osoblyvosti vykladannia ta vyvchennia anhliiskoii movy psykhologichnoho napriamu u vyschikh navchalnykh zakladakh [ Peculiarities of Teaching and Learning the English Language for Psychologists in Higher Education Settings]. Psykholohopedahohichni problemy silskoi schkoly: zb. nauk. pr. Psychological and Pedagogical Issues of Village Schools, 33, 87-93. N.S. Pobirchenko (Ed.). Uman [in Ukrainian].

2. Buran, A. \& Filyukov, A. (2015). Mind Mapping Technique in Language Learning. Available in ProcediaSocial and Behavioral Sciences, 206, 215-218. Retrieved from: http://www.researchgate.net/publication/ 283983705_Mind_Mapping_Technique_in_Language_Le arning [in English].

3. Buzan, T. (2003). Mind Maps for Kids: an Introduction. London: Harper Thorsons [in English].

4. Left Brain vs. Right Brain Function in Learning (2011). Retrieved from: http://funderstanding.com/brain/ left-brain-vs-right-brain-function-in-learning/ [in English].

5. Hanewald, R. (2012). Cultivating Life-long Learning Skills in Undergraduate Students through the Collaborative Creation of Digital Knowledge Maps. Available in Procedia - Social and Behavioral Sciences, 69, 847-853. Retrieved from: http://doi.org/10.1016/j.sbspro.2012 12.007 [in English].

6. Jones, B.D., Ruff, C. et al. (2012). The Effects of Mind Mapping Activities on Students' Motivation. International Journal for the Scholarship of Teaching and Learning, 1, (Vol. 6). Retrieved from: http://doi.org/10.20429/ijsotl.2012.060105 [in English].

7. Long, D. \& Carson, D. (2011). Mind the Map: How Thinking Maps Affect Student Achievement. Network: an Online Journal for Teacher Research, 2, (Vol. ing ESP, are of great significance for their implementation in higher educational institutions. The research outcomes have shown the effectiveness of implementing the mind-mapping technique into the university course teaching the ESP to develop, advance and master students' professional communicative competence. The mindmapping technique will promote better performance during study sessions and create a less tense atmosphere in the classroom.

As for the further researches in this field, studies of the role and place of mind maps in alleviating anxiety in academic environment and research concerning activity boost during the course in ESP in higher educational institutions are worth noticing.

To sum up it is significant to state that profound studying of mind map characteristics and features of their implementation in ESP lessons; as well as consistent use of mind maps will have positive impact on the overall training of competitive skilled specialists and their employment options in the present-day socially mobile world.

13). Retrieved from: http://journals.library.wisc.edu/ index.php/networks/article/download/262/496 [in English].

8. Melrose, S. (2013). Facilitating Constructivist Learning Environments Using Mind Maps and Concept Maps as Advance Organizers. Institute for Learning Centred Education. Retrieved from: http://auspace.athabascau.ca /bitstream/handle/2149/3387/2013-1-

melrose.pdf?sequence=1\&isAllowed=y [in English].

9. Radix, C.-A., Abdool, A. (2013). Using Mind Maps for the Measurement and Improvement of Learning Quality. Caribbean Teaching Scholar, 1, 3-21, (Vol. 3). Retrieved from: libraries.sta.uwi.edu/journals/ojs/ index.php/cts/view/358 [in English].

10. Reel, J., Langer, S. (2011). An Exploratory Analysis of Mind Maps. Proceedings of the $11^{\text {th }}$ ACM Symposium on Document Engineering (DocEng'11), Mountain View, California, USA, pp.81-84, ACM. Retrieved from: http://www.docear.org/papers/An\%20 Exploratory $\% 20$ Analysis $\% 20$ of\%20Mind $\% 20$ Maps $\% 20-$ $\% 20$ preprint.pdf [in English].

11. Zahedi, M. \& Heaton, L. (2016). Mind Mapping as a tool, as a process, as a problem/solution place. International Conference on Engineering and Product Design Education, 2016, Sept. 8-9, Aalborg University, Denmark. Retrievd from: http://www.amenagement.umontreal. ca/fileadmin/DES/Professeurs/PDF/Zahedi/2016-

E_PDE16-MZahedi-LHeaton.pdf [in English].

12. Zipp, G. \& Maher, C. (2013). Prevalence of Mind Mapping as a Teaching and Learning Strategy in Physical Therapy Curricula. Journal of the Scholarship Teaching and Learning, 5, 21-32, (Vol. 13). Retrieved from: http://files.eric.ed.gov/fulltext/EJ1017130.pdf [in English]. 


\section{ЛІТЕРАТУРА}

1. Орлова Н.В. Особливості викладання та вивчення англійської мови психологічного напряму у ВНЗ / Н.В. Орлова // Психолого-педагогічні проблеми сільської школи: зб. наук. праць Уманського державного педагогічного університету імені Павла Тичини / Ред. кол.: Н.С. Побірченко (гол. ред.) та ін. - Умань: ПП Жовтий, 2010. - Вип. 33. - С. 87-93

2. Buran Anna, Filyukov Andrey. Mind Mapping Technique in Language Learning / Anna Buran, Andrey Filyukov // Procedia - Social and Behavioral Sciences, 2015. - Vol. 206. - 215-218 pp. [Електронний ресурс]. - Режим доступу: http: //www.researchgate.net/publication/283983705_Mind_M apping_Technique_in_Language_Learning

3. Buzan Tony Mind Maps for Kids: an Introduction / Tony Buzan. - London: Harper Thorsons, 2003. - 128 p.

4. Left Brain vs. Right Brain Function in Learning [Site Funderstanding]. [Електронний pecypc]. www.funderstanding.com - Режим доступу: http://funderstanding.com/brain/left-brain-vs-right-brainfunction-in-learning/

5. Hanewald R. Cultivating Life-long Learning Skills in Undergraduate Students through the Collaborative Creation of Digital Knowledge Maps. / R. Hanewald // Procedia - Social and Behavioral Sciences, 2012. - Vol. 69. - 847-853pp. [Електронний ресурс]. - Режим доступу: http://doi.org/10.1016/j.sbspro.2012.12.007

6. Jones B.D. The Effects of Mind Mapping Activities on Students' Motivation / B. D. Jones, C. Ruff // International Journal for the Scholarship of Teaching and Learning, 2012. Vol. 6, № 1, Article 5. [Електронний ресурс]. - Режим доступу: http://doi.org/10.20429/ijsotl.2012.060105

7. Long D. Mind the Map: How Thinking Maps Affect Student Achievement / D. Long, D. Carson // Network: an Online Journal for Teacher Research, 2011. Vol. 13, Issue 2. [Електронний ресурс]. - Режим дос- тупу: http://journals.library.wisc.edu/index.php/networks/ article/download/262/496

8. Melrose S. Facilitating Constructivist Learning Environments Using Mind Maps and Concept Maps as Advance Organizers / S. Melrose // Institute for Learning Centred Education, 2013. хЕлектронний ресурсъю Режим доступу: http://auspace.athabascau.ca/bitstream/ handle/2149/3387/2013-1-melrose.pdf?sequence $=1 \&$ is Allowed=y

9. Radix C.-A. Using Mind Maps for the Measurement and Improvement of Learning Quality / C.-A. Radix, A. Abdool // Caribbean Teaching Scholar, 2013. Vol. 3, № 1, 3-21 pp. [Електронний ресурс]. - Режим доступу: libraries.sta.uwi.edu/journals/ojs/index.php/cts/view/358

10. Reel J. An Exploratory Analysis of Mind Maps. / J. Reel, S. Langer // Proceedings of the $11^{\text {th }}$ ACM Symposium on Document Engineering (DocEng'11), Mountain View, California, USA, pp.81-84, 2011. ACM. [Електронний ресурс]. - Режим доступу: http://www.docear.org/papers/An\%20Exploratory\%20An alysis\%20of\%20Mind\%20Maps\%20--\%20preprint.pdf

11. Zahedi M. Mind Mapping as a tool, as a process, as a problem/solution place / M. Zahedi, L. Heaton // International Conference on Engineering and Product Design Education, 2016, Sept. 8-9, Aalborg University, Denmark. [Електронний pecyрc]. - Режим доступу: http://www.amenagement.umontreal.ca/fileadmin/DES/Pr ofesseurs/PDF/Zahedi/2016-E_PDE16-MZahedi-

LHeaton.pdf

12. Zipp G., Maher C. Prevalence of Mind Mapping as a Teaching and Learning Strategy in Physical Therapy Curricula / G. Zipp, C. Maher // Journal of the Scholarship Teaching and Learning, 2013. - Vol. 13, №5, pp. 2132. [Електронний ресурс]. - Режим доступу: http://files.eric.ed.gov/fulltext/EJ1017130.pdf

\section{Наталія Володимирівна Орлова, кандидат педагогічних наук, доиент кафедри іноземних мов, Навчально-науковий інститут іноземних мов, Черкаський національний університет імені Богдана Хмельницького, бульвар Шевченка, 81, м. Черкаси, Украӥна}

\section{ЗНАЧЕННЯ МЕНТАЛЬНОГО МАПУВАННЯ У ПОКРАЩЕННІ УСНОГО МОВЛЕННЯ У СТУДЕНТІВ НЕМОВНИХ СПЕЦАЛЬНОСТЕЙ}

Тренування професійного мовленнєвого спілкування дозволяє навчити студентів немовних спеціальностей підкріплювати тему бесіди фактами з дисципліни профілю майбутньої спеціальності, активізує процес засвоєння, а також мотивацію. Формування навичок усного монологічного мовлення як одне із завдань курсу з іноземної мови професійного спрямування пов'язане з окремими труднощами, що можуть гальмувати навчальний процес і демотивувати студентів під час його вивчення. У переліку стратегій і технік, що застосовуються для покращення результатів вивчення іноземної мови професійного спрямування, зокрема, у монологічному мовленні з фахових тем, окреме місце посідають ментальні карти як цікавий і корисний інструмент у покращенні якості монологічного мовлення студентів-психологів як представників нелінгвістичних спеціальностей. У статті було проаналізовано дослідження щодо фасилітаційного впливу ментальних карт на якість усного монологічного мовлення студентів немовних спеціальностей. Гіпотеза про те, що використання техніки ментального мапування у процесі підготовки та під час усної доповіді на заняттях з іноземної (англійської) мови за професійним спрямуванням покращує успішність і результати навчання, була підтверджена позитивними результатами. Студенти з експериментальної групи, які впродовж роботи 
над темою користувались технікою ментального мапування, продемонстрували кращу успішність і володіння матеріалом. Використання ментальних карт залучає активну роботу обох півкуль головного мозку, чим сприяє полегшеному запам'ятовуванню тематичного матеріалу, кращій орієнтації у ключових поняттях, спрощує дотримання логіки висловлювання під час презентації теми. За результатами дослідження можна підсумувати, що використання на заняттях з іноземної мови професійного спрямування ментальних карт допоможе підвищити ефективність навчального процесу і буде позитивно впливати на формування майбутніх мобільних фахівців.

Ключові слова: ментальні карти, техніка ментального мапування, іноземна мова професійного спрямування, усне монологічне висловлювання, немовні спеціальності.

Submitted on June, 5, 2017

Reviewed by Doctor of Pedagogy, prof. S. Danyliuk

УДК: $371.2: 514.18$

DOI: https://doi.org/10.24195/2414-4665-2017-6-24

Наталія Валеріївна Сидорова, кандидат технічних наук, дочент, Вероніка Валентинівна Думанська, кандидат технічних наук,

Юлія Валеріївна Доценко, кандидат технічних наук, кафедра нарисної геометрії та інженерної графіки, Одеська державна академія будівництва та архітектури, вул. Дідріхсона, 4, м. Одеса, Україна

\section{МЕТОДИ ПІДВИЩЕННЯ ЕФЕКТИВНОСТІ ТА ЯКОСТІ ВИКЛАДАННЯ НАРИСНОЇ ГЕОМЕТРЇ̈}

Низький рівень підготовки студентів висуває особливі вимоги до методів навчання. Умови щзодо змісту і якості графічної підготовки викликають необхідність вдосконалення форми і методів організації індивідуальної та самостійної роботи студентів. Розроблено нові методи викладання дисиипліни студентам спеціальності 191 «Архітектура та містобудування». 3 метою підвищення ефективності та якості викладання авторами розроблено та виготовлено демонстраційні стенди. Стенд для демонстрації тіней макетів запропоновано для вивчення розділу «Тіні», а стенд «дзеркальна кімната» - для вивчення розділу «Відображення». У статті детально описуються обидва розроблених демонстрачійних стенди та наведено їх наочні зображення. Для виявлення переваг запропоновані методи викладання були впроваджені в навчальний процес. В експериментальній групі студенти виконували завдання з використанням розроблених демонстраційних стендів. У статті також досліджуються критерії, щзо характеризують очінювання якості робіт та термін їх виконання при вивченні тем «Тіні» та «Відображення». Наведено дані цих показників для групи студентів, які навчалася за новою методикою, та тих, хто навчався за традиційною схемою без використання розроблених макетів. Отримані результати вказують на переваги нових методів викладання та підтверджують гіпотезу дослідження. Порівняльний аналіз вихідних параметрів свідчить про те, щзо розроблені методи сприяють кращцому розумінню та засвоєнню тем занять, щчо, в свою чергу, веде до заохочення студентів до навчання. Запропоновані методи сприяють більи глибокому розумінню матеріалу, вчать переносити на креслення реальні об'єкти та будувати відображення, щзо, відповідно веде до підвищення успішності. Використання розроблених методів при проведенні занять сприяє підвищенню творчого потенціалу студентів, допомагає розвинути їх об’ємно-просторове мислення, внаслідок чого підвищується рівень підготовки майбутніх фахівиів. Упровадження у навчальний прочес пропонованих нових методів допоможе викладачам нарисної геометрї удосконалити процес навчання з иуієї дсичилліни.

Ключові слова: графічна підготовка, побудова та читання креслення, методи навчання, ефективність та якість підготовки студентів, нарисна геометрія, наочні посібники, успішність студентів, демонстраційний стенд.

\section{Постановка проблеми}

У сучасному світі техніки неможливо обійтися без знання графічних наук, уміння розробляти, читати й аналізувати графічну інформацію. Отже, рівень і якість графічної освіти - це головні показники загальновизнаної підготовки майбутнього фахівця. Сьогодні ми не можемо говорити про достатній рівень графічної підготовки, а зміни, які відбуваються в усіх сфеpax життя, вимагають підвищення рівня конкурентоспроможності випускників ВНЗ.

За останні роки рівень графічної підготовки студентів різко знизився. За даними проведеного 